\title{
Study of Mathematical Models in Hot Air Drying of Herbs in Herbal Compress Ball
}

\author{
Boochita Wongpanit ${ }^{1}$, Sumitta Chotikamas ${ }^{2}$, Supacharee Roddecha ${ }^{3}$, Prapakorn Tantayotai ${ }^{4}$ and Malinee Sriariyanun ${ }^{1}$ \\ ${ }^{1}$ The Sirindhorn International Thai-German Graduate School of Engineering, King Mongkut's University of Technology North Bangkok, \\ Bangkok 10800, Thailand \\ ${ }^{2}$ Department of Chemical Engineering, Faculty of Engineering, King Mongkut's University of Technology North Bangkok, Bangkok 10800 , \\ Thailand \\ ${ }^{3}$ Department of Chemical Engineering, Faculty of Engineering, Kasetsart University, Bangkok 10900, Thailand \\ ${ }^{4}$ Microbiology Department of Microbiology, Faculty of Science, Srinakarinwirot University, Bangkok 10110, Thailand
}

\begin{abstract}
Herbal compress ball is currently one of important products of Thailand for exporting sales worldwide. It is used in Thai traditional medical treatment and spa to reduce muscle pain and relaxation. This research aimed to generate the mathematical models representing the behaviors of herbs in hot air drying to extend shelf life for exporting sales. Here, six types of herbs, including Prai (Zingiber cassumunar Roxb.), Turmeric (Curcuma longa Linn.), Lemongrass (Cymbopogon citratus), Kaffir lime (Citrus hystrix), Soap Pod leaves (Acacia concinna) and Tamarind Leaves (Tamarindus indica Linn.) were dried in different temperature at 60,70 , and $80^{\circ} \mathrm{C}$. Fours drying models, Page, Henderson and Pabis, and Logarithmic and Fick's second law equation were applied with experimental data of drying herbs to predict the rate of diffusion of water. The results showed that the Page model is the most suitable model due to the highest decision coefficient $\left(\mathrm{R}^{2}\right)$ but the lowest Root Mean Square Error (RMSE). The effective moisture diffusivity $\left(\mathrm{D}_{\text {eff }}\right)$ of the herbs in herbal compress ball was increased with increased the drying temperature. The size of the herb particle translated inversely with effective moisture diffusivity $\left(\mathrm{D}_{\text {eff }}\right)$ value.
\end{abstract}

\section{Introduction}

Based on data from the World Health Organization (WHO), $80 \%$ of the population in developing countries have used traditional medicine and herbs for treatment of sickness and nourishing health. Applications of herbs for these purposes has been inherited and developed for a long time [1]. One of applications of herbs in Thailand is in the form of herbal compress, so called Luk-Prakob in Thai, that various types of mixed herbs are wrapped in the thin cheese clothes. Thai herbal compress is mainly used in muscle pain treatment and in spa [2]. The medicinal effects of herbal compress depend on the composition of herbs in the compress.

One of the traditional formula of Thai compress consists of 6 types of herbs, including Prai (Zingiber cassumunar Roxb.), Turmeric (Curcuma longa Linn.), Lemongrass (Cymbopogon citratus), Kaffir lime (Citrus hystrix), Soap Pod leaves (Acacia concinna), and Tamarind Leaves (Tamarindus indica Linn.). Several previous studies reported that Prai (Zingiber cassumunar Roxb.), kaffir lime (Citrus hystrix) [3], Tamarind Leaves (Tamarindus indica Linn.) [4], and turmeric (Curcuma longa Linn.) [5] have anti-inflammatory activities. Lemongrass (Cymbopogon citratus) posesses anti-oxidant, anti-microbial and anti-fungal activities [6]. Soap Pod leaves (Acacia concinna) has major compositions, such as phenolics, flavonoids, and carotenoids that have antioxidant activities [7].

Herbal compress product has one important limitation of storage because herbs in the herbal compress ball have high moisture causing the growth of microorganisms and spoilage. Therefore, the drying process is a necessary process in preserving the product for a longer shelf life. By reducing moisture or water content in the product to inhibit the microorganisms that cause the spoilage products [8]. Hot air drying is the most common technique in the industry by providing hot air flow through wet material.

The principle of drying process involves heat and mass transfer [9]. Mathematical Modelling is a method for prediction the change of moisture content in the product during drying in the experiment. The information obtained from the model such as initial moisture content, drying time, temperature, and energy values could be used to design a better efficient dryer to save time and cost [10-12]. However, each drying model still has limitation that could be applied in different experimental scenario. In this research, we focused on studying the drying process of the herbs in herbal compress ball with a hot air dryer to select the appropriate mathematical model that fit well to the experimental data. 


\section{Materials and methods}

\subsection{Material preparation}

The fresh plant materials, including Prai (Zingiber cassumunar Roxb.), Turmeric (Curcuma longa Linn.), Lemongrass (Cymbopogon citratus), Kaffir lime (Citrus hystrix), and Tamarind Leaves (Tamarindus indica Linn.), were purchased from the local market in Bangkok, Thailand. The samples were washed with distilled water, dried with ambient air (approximately $30^{\circ} \mathrm{C}$ ) and were prepared into 2 sizes, uncut and cut samples, then followed by size screening with sieve shakers at mesh no. 10 (avg. size $1.5 \mathrm{~mm}$ ), and stored in a refrigerator at $4 \pm$ $0.5^{\circ} \mathrm{C}$ before the experiment.

\subsection{Drying system and procedure}

A hot-air convention dryer was used. The characteristic of dryer chamber is $370 \mathrm{~mm} \times 340 \mathrm{~mm} \times 420 \mathrm{~mm}$. The air flow was forced through to chamber by using a blower in horizontal direction and then was heated as it passed through coil heaters that had a heat capacity of 900 Watt, operated at $230 \mathrm{~V}, 1$ phase, and $60 \mathrm{HZ}$. The drying of samples were operated at 3 temperature levels are 60,70, $80{ }^{\circ} \mathrm{C}$. After the dryer conditions were adjusted for the experiment plan then $200 \mathrm{~g}$ of plant materials was place in dryer and measure the weight of the remaining samples from drying every 30 minutes until constant weight.

\subsection{Mathematic model and drying rate}

The selected mathematical models used in this study are shown in Table 1. By the moisture ratio (MR) of herbs in Thai herbal compress ball during drying was calculated by using Eq. 1 .

$$
M R=\frac{M t-M e q}{M i-M e q}
$$

where $\mathrm{M}_{\mathrm{t}}$ is the moisture content at any time of herbs in Thai herbal compress ball, $\mathrm{M}_{\mathrm{i}}$ is the initial moisture content of herbs in Thai herbal compress ball, and $\mathrm{M}_{\mathrm{eq}}$ is the equilibrium moisture content of herbs in Thai herbal compress ball. For the dried agricultural products, the equilibrium moisture content can be assumed to be zero because the values of $\mathrm{M}_{\mathrm{eq}}$ are relatively low when compared to $\mathrm{M}_{\mathrm{t}}$ or $\mathrm{M}_{\mathrm{i}}$ [13]. For this reason, the moisture ratio was calculated by using Eq. 2 .

$$
M R=\frac{M t}{M i}
$$

The mathematical models (Table 1) used to find the optimal model for describing the drying curve of herbs in Thai herbal compress ball. Non-linear regression was used to achieve each constant parameter of selected mathematical models by using the MATLAB program for selecting the best model for describing the drying curves of the experiment.

\subsection{Statistical analysis for determination of appropriate model.}

Table 1. The mathematical models used in this study.

\begin{tabular}{|c|c|c|c|}
\hline No. & Model name & Model equation & Reference \\
\hline 1 & Page & $\mathrm{MR}=\exp \left(-\mathrm{kt} \mathrm{n}^{\mathrm{n}}\right)$ & {$[14]$} \\
\hline 2 & $\begin{array}{c}\text { Henderson and } \\
\text { Pabis }\end{array}$ & $\mathrm{MR}=\mathrm{a} \cdot \exp (-\mathrm{kt})$ & {$[15]$} \\
\hline 3 & Logarithmic & $\mathrm{MR}=\mathrm{a} \cdot \exp (-\mathrm{kt})+\mathrm{c}$ & {$[16]$} \\
\hline
\end{tabular}

where $\mathrm{a}, \mathrm{k}, \mathrm{c}$ and $\mathrm{n}$ are constant parameter; $\mathrm{t}$ is drying time (sec).

The correlation coefficient $\left(\mathrm{R}^{2}\right)$ and root mean square error (RMSE) were used to evaluate the best mathematical model for drying herb in Thai herbal compress ball. The best value of correlation coefficient $\left(\mathrm{R}^{2}\right)$ is high (closer to one) and the value of root mean square error (RMSE) is low (closer to zero) [17]. These two parameters could be calculated by using Eq. (3)-(4):

$$
\begin{gathered}
R^{2}=1-\frac{\sum_{i=1}^{N} \cdot\left(M R_{\text {pre }, i}-M R_{\text {exp }, i}\right)^{2}}{\sum_{i=1}^{N}\left(\overline{M R}, \exp -M R_{\text {pre }, i}\right)^{2}} \\
R M S E=\sqrt{\frac{1}{N} \sum_{i=1}^{N}\left(M R_{\text {pre }, i}-M R_{\text {exp }, i}\right)^{2}}
\end{gathered}
$$

where $M R_{\text {exp, } i}$ is the $i^{\text {th }}$ experimental value, $\mathrm{MR}_{\text {pre, } \mathrm{i}}$ is the $i^{\text {th }}$ predicted value, $M R_{\text {exp,ave }}$ is the $i^{\text {th }}$ experimental average value, $\mathrm{N}$ is the total number of observations.

\subsection{Effective moisture diffusivity.}

Fick's law of Diffusion was used to describe the water movement of herbs in the herbal compress ball during drying. The migration rate of water molecules or moisture within herb materials could be directly affected by the shapes of materials [18-20]. The equation can be expressed by Eq. 5- Eq. 7.

In this study, Prai (Zingiber cassumunar Roxb.), Turmeric (Curcuma longa Linn.), and Lemongrass (Cymbopogon citratus), were assumed to be cylindrical to find the effective moisture diffusivity $\left(D_{\text {eff }}\right)$. And the equation for a cylindrical shape can be expressed by Eq.5

$$
M R=\frac{M t-M e q}{M i-M e q}=4 \cdot \exp \left(-\frac{\text { Deff.t }}{R^{2}}\right)
$$

For Tamarind Leaves (Tamarindus indica Linn.) and Kaffir lime (Citrus hystrix) were assumed to be infinite slab to find the effective moisture diffusivity ( $\left.D_{\text {eff }}\right)$. Equation can be expressed by Eq.6

$$
M R=\frac{M t-M e q}{M i-M e q}=\frac{8}{\pi^{2}} \exp \left(-\pi^{2} \frac{\text { Deff.t }}{4 L^{2}}\right)
$$

and the equation for a spherical shape was described the reduced size material as show in Eq. 7 
Table 2. Statistical analysis with the Page, Henderson and Pabis and logarithmic model on drying process.

\begin{tabular}{|c|c|c|c|c|c|}
\hline $\begin{array}{l}\text { Drying } \\
\text { model }\end{array}$ & Sample & $\begin{array}{c}\text { Temperature } \\
\left({ }^{\circ} \mathrm{C}\right) \\
\end{array}$ & Drying Model Constants & $\mathrm{R}^{2}$ & RMSE \\
\hline \multirow{15}{*}{ Page } & \multirow{3}{*}{$\begin{array}{l}\text { Prai } \\
\text { (Zingiber cassumunar Roxb.) }\end{array}$} & 60 & $\mathrm{k}=0.000304, \mathrm{n}=1.365$ & 0.9974 & 0.01519 \\
\hline & & 70 & $\mathrm{k}=0.004204, \mathrm{n}=1.000$ & 0.9989 & 0.01045 \\
\hline & & 80 & $\mathrm{k}=0.003291, \mathrm{n}=1.061$ & 0.9910 & 0.02812 \\
\hline & \multirow{3}{*}{$\begin{array}{l}\text { Turmeric } \\
\text { (Curcuma longa Linn.) }\end{array}$} & 60 & $\mathrm{k}=0.000477, \mathrm{n}=1.262$ & 0.9969 & 0.01584 \\
\hline & & 70 & $\mathrm{k}=0.004542, \mathrm{n}=1.012$ & 0.9974 & 0.01519 \\
\hline & & 80 & $\mathrm{k}=0.001706, \mathrm{n}=1.221$ & 0.9996 & 0.00627 \\
\hline & \multirow{3}{*}{$\begin{array}{l}\text { Lemongrass } \\
\text { (Cymbopogon citratus) }\end{array}$} & 60 & $\mathrm{k}=0.000306, \mathrm{n}=1.386$ & 0.9987 & 0.01141 \\
\hline & & 70 & $\mathrm{k}=0.000635, \mathrm{n}=1.327$ & 0.9962 & 0.01993 \\
\hline & & 80 & $\mathrm{k}=0.002676, \mathrm{n}=1.079$ & 0.9966 & 0.01770 \\
\hline & \multirow{3}{*}{$\begin{array}{l}\text { Kaffir lime } \\
\text { (Citrus hystrix) }\end{array}$} & 60 & $\mathrm{k}=0.001765, \mathrm{n}=1.262$ & 0.9984 & 0.01341 \\
\hline & & 70 & $\mathrm{k}=0.002703, \mathrm{n}=1.219$ & 0.9993 & 0.00864 \\
\hline & & 80 & $\mathrm{k}=0.003286, \mathrm{n}=1.258$ & 0.9991 & 0.00967 \\
\hline & \multirow{3}{*}{$\begin{array}{l}\text { Tamarin } \\
\text { (Tamarindus indica } \text { Linn.) }\end{array}$} & 60 & $\mathrm{k}=0.002149, \mathrm{n}=1.385$ & 0.9981 & 0.01618 \\
\hline & & 70 & $\mathrm{k}=0.010070, \mathrm{n}=1.150$ & 0.9970 & 0.01931 \\
\hline & & 80 & $\mathrm{k}=0.004381, \mathrm{n}=1.322$ & 0.9913 & 0.03422 \\
\hline \multirow{15}{*}{$\begin{array}{l}\text { Henderson } \\
\text { and Pabis }\end{array}$} & \multirow{3}{*}{$\begin{array}{l}\text { Prai } \\
\text { (Zingiber cassumunar Roxb.) }\end{array}$} & 60 & $\mathrm{a}=1.011, \mathrm{k}=0.004919$ & 0.9975 & 0.01478 \\
\hline & & 70 & $\mathrm{a}=0.047, \mathrm{k}=0.006708$ & 0.9965 & 0.01870 \\
\hline & & 80 & $\mathrm{a}=1.013, \mathrm{k}=0.008602$ & 0.9908 & 0.02828 \\
\hline & \multirow{3}{*}{$\begin{array}{l}\text { Turmeric } \\
\text { (Curcuma longa Linn.) }\end{array}$} & 60 & $\mathrm{a}=1.047, \mathrm{k}=0.002333$ & 0.9873 & 0.03191 \\
\hline & & 70 & $\mathrm{a}=1.011, \mathrm{k}=0.004919$ & 0.9975 & 0.01478 \\
\hline & & 80 & $\mathrm{a}=1.061, \mathrm{k}=0.005880$ & 0.9937 & 0.02591 \\
\hline & \multirow{3}{*}{$\begin{array}{l}\text { Lemongrass } \\
\text { (Cymbopogon citratus) }\end{array}$} & 60 & $\mathrm{a}=1.084, \mathrm{k}=0.003069$ & 0.9841 & 0.03939 \\
\hline & & 70 & $\mathrm{a}=1.077, \mathrm{k}=0.004226$ & 0.9842 & 0.04094 \\
\hline & & 80 & $\mathrm{a}=1.026, \mathrm{k}=0.004256$ & 0.9959 & 0.01950 \\
\hline & \multirow{3}{*}{$\begin{array}{l}\text { Kaffir lime } \\
\text { (Citrus hystrix) }\end{array}$} & 60 & $\mathrm{a}=1.059, \mathrm{k}=0.007230$ & 0.9890 & 0.03474 \\
\hline & & 70 & $\mathrm{a}=1.045, \mathrm{k}=0.008456$ & 0.9924 & 0.02843 \\
\hline & & 80 & $\mathrm{a}=1.043, \mathrm{k}=0.011540$ & 0.9911 & 0.03114 \\
\hline & \multirow{3}{*}{$\begin{array}{l}\text { Tamarin } \\
\text { (Tamarindus indica } \text { Linn.) }\end{array}$} & 60 & $\mathrm{a}=1.056, \mathrm{k}=0.013210$ & 0.9815 & 0.05036 \\
\hline & & 70 & $\mathrm{a}=1.012, \mathrm{k}=0.019180$ & 0.9944 & 0.02649 \\
\hline & & 80 & $\mathrm{a}=1.028, \mathrm{k}=0.017870$ & 0.9811 & 0.05047 \\
\hline \multirow{15}{*}{ Logarithmic } & \multirow{3}{*}{$\begin{array}{l}\text { Prai } \\
\text { (Zingiber cassumunar Roxb.) }\end{array}$} & 60 & $\mathrm{a}=0.998, \mathrm{k}=0.005178, \mathrm{c}=0.01987$ & 0.9981 & 0.01328 \\
\hline & & 70 & $\mathrm{a}=1.052, \mathrm{k}=0.006540, \mathrm{c}=-0.00945$ & 0.9967 & 0.01874 \\
\hline & & 80 & $\mathrm{a}=1.002, \mathrm{k}=0.009182, \mathrm{c}=0.02055$ & 0.9925 & 0.02645 \\
\hline & \multirow{3}{*}{$\begin{array}{l}\text { Turmeric } \\
\text { (Curcuma longa Linn.) }\end{array}$} & 60 & $\mathrm{a}=1.122, \mathrm{k}=0.002031, \mathrm{c}=-0.08468$ & 0.9908 & 0.02797 \\
\hline & & 70 & $\mathrm{a}=0.998, \mathrm{k}=0.005178, \mathrm{c}=0.01987$ & 0.9981 & 0.01328 \\
\hline & & 80 & $\mathrm{a}=1.085, \mathrm{k}=0.005429, \mathrm{c}=-0.03345$ & 0.9955 & 0.02257 \\
\hline & \multirow{3}{*}{$\begin{array}{l}\text { Lemongrass } \\
\text { (Cymbopogon citratus) }\end{array}$} & 60 & $\mathrm{a}=1.138, \mathrm{k}=0.002752, \mathrm{c}=-0.06361$ & 0.9869 & 0.03694 \\
\hline & & 70 & $\mathrm{a}=1.112, \mathrm{k}=0.003869, \mathrm{c}=-0.04453$ & 0.9862 & 0.03944 \\
\hline & & 80 & $\mathrm{a}=1.031, \mathrm{k}=0.004188, \mathrm{c}=-0.00721$ & 0.9959 & 0.01995 \\
\hline & \multirow{3}{*}{$\begin{array}{l}\text { Kaffir lime } \\
\text { (Citrus hystrix) }\end{array}$} & 60 & $\mathrm{a}=1.102, \mathrm{k}=0.006166, \mathrm{c}=-0.06335$ & 0.9952 & 0.02365 \\
\hline & & 70 & $\mathrm{a}=1.079, \mathrm{k}=0.007314, \mathrm{c}=-0.05324$ & 0.9974 & 0.01719 \\
\hline & & 80 & $\mathrm{a}=1.067, \mathrm{k}=0.010420, \mathrm{c}=-0.03623$ & 0.9948 & 0.02483 \\
\hline & \multirow{3}{*}{$\begin{array}{l}\text { Tamarin } \\
\text { (Tamarindus indica Linn.) }\end{array}$} & 60 & $\mathrm{a}=1.120, \mathrm{k}=0.010730, \mathrm{c}=-0.08503$ & 0.9918 & 0.03558 \\
\hline & & 70 & $\mathrm{a}=1.012, \mathrm{k}=0.019190, \mathrm{c}=1.427 \mathrm{E}-13$ & 0.9944 & 0.02649 \\
\hline & & 80 & $\mathrm{a}=1.063, \mathrm{k}=0.015870, \mathrm{c}=-0.04438$ & 0.9861 & 0.04631 \\
\hline
\end{tabular}


Table 3. Effective moisture diffusivity at different temperature.

\begin{tabular}{|c|c|c|c|c|c|c|c|c|c|c|}
\hline \multirow{3}{*}{$\begin{array}{c}\text { Temperature } \\
\left({ }^{\circ} \mathrm{C}\right)\end{array}$} & \multicolumn{10}{|c|}{ Effective Moisture Diffusivity $\left(\mathrm{D}_{\text {eff }}\right)\left[\mathrm{m}^{2} / \mathrm{s}\right]$} \\
\hline & \multicolumn{2}{|c|}{ Prai } & \multicolumn{2}{|c|}{ Turmeric } & \multicolumn{2}{|c|}{ Lemongrass } & \multicolumn{2}{|c|}{ Tamarin } & \multicolumn{2}{|c|}{ Kaffir lime } \\
\hline & $\begin{array}{l}\text { Uncut } \\
\text { size }\end{array}$ & $\begin{array}{c}\text { Cut size } \\
\text { (avg.1.5 } \\
\text { mm) }\end{array}$ & $\begin{array}{l}\text { Uncut } \\
\text { size }\end{array}$ & $\begin{array}{c}\text { Cut size } \\
\text { (avg.1.5 } \\
\text { mm) }\end{array}$ & $\begin{array}{l}\text { Uncut } \\
\text { size }\end{array}$ & $\begin{array}{c}\text { Cut size } \\
\text { (avg.1.5 } \\
\text { mm) }\end{array}$ & $\begin{array}{l}\text { Uncut } \\
\text { size }\end{array}$ & $\begin{array}{c}\text { Cut size } \\
\text { (avg.1.5 } \\
\text { mm) }\end{array}$ & $\begin{array}{l}\text { Uncut } \\
\text { size }\end{array}$ & $\begin{array}{c}\text { Cut size } \\
\text { (avg.1.5 } \\
\text { mm) }\end{array}$ \\
\hline 60 & $1.10 \mathrm{E}-03$ & 5.30E-04 & 6.82E-05 & $8.86 \mathrm{E}-05$ & 7.11E-05 & 4.84E-06 & $2.86 \mathrm{E}-04$ & $1.59 \mathrm{E}-04$ & 4.37E-04 & 8.93E-04 \\
\hline 70 & $1.29 \mathrm{E}-03$ & $1.42 \mathrm{E}-02$ & $8.26 \mathrm{E}-05$ & $9.04 \mathrm{E}-05$ & 7.85E-05 & $1.62 \mathrm{E}-04$ & 4.37E-04 & 7.96E-02 & 5.34E-04 & $4.68 \mathrm{E}-01$ \\
\hline 80 & $1.32 \mathrm{E}-03$ & $1.93 \mathrm{E}-02$ & $8.97 \mathrm{E}-05$ & 1.44E-04 & 8.02E-05 & 2.52E-04 & $4.25 \mathrm{E}-04$ & $1.02 \mathrm{E}-01$ & 7.76E-04 & $6.95 \mathrm{E}-01$ \\
\hline
\end{tabular}

$$
M R=\frac{M t-M e q}{M i-M e q}=\frac{6}{\pi^{2}} \cdot \exp \left(-\pi^{2} \frac{\text { Deff } . t}{R^{2}}\right)
$$

where $D_{\text {eff }}$ is effective moisture diffusivity in $\mathrm{m}^{2} / \mathrm{s}, \mathrm{L}$ is the thickness of sample in infinite slab equation $(\mathrm{m}), \mathrm{t}$ is drying time ( $\mathrm{sec})$, and $\mathrm{R}$ is the radius of the sample in cylinder equation.

\section{Results and discussion.}

\subsection{A drying characteristics of the herbs in herbal compress balls.}

Based on the experimental data, the values of moisture ratio with a drying time of 5 different types of herbs at $60-80{ }^{\circ} \mathrm{C}$ were demonstrated in Figure 1a-1c. Drying behavior of herb materials showed the moisture in samples rapidly reduced in the early phase of drying, and the drying rate was reduced at the later phase until the moisture equilibrium was achieved [21]. In this study, among all types of herbs tested, Prai (Zingiber cassumunar Roxb.) has the lowest moisture reducing rate at $60{ }^{\circ} \mathrm{C}$, following by Turmeric (Curcuma longa Linn.), Lemongrass (Cymbopogon citratus), Kaffir lime (Citrus hystrix), and Tamarind Leaves (Tamarindus indica Linn.), respectively (Figure 1a). At $70{ }^{\circ} \mathrm{C}$, Lemongrass (Cymbopogon citratus) has the lowest moisture reduction rate, following by Prai (Zingiber cassumunar Roxb.), Turmeric (Curcuma longa), Kaffir lime (Citrus hystrix) and Tamarin (Tamarindus indica Linn.), respectively. However, after 300 minutes of drying time, Prai (Zingiber cassumunar Roxb.) turned to have the lowest moisture reduction rate instead. At $80{ }^{\circ} \mathrm{C}$, Lemongrass (Cymbopogon citratus) has a lowest moisture reduction rate, following by Prai (Zingiber cassumunar Roxb.), Turmeric (Curcuma longa Linn.), Kaffir lime (Citrus hystrix), and Tamarind Leaves (Tamarindus indica Linn.), respectively.

\subsection{Drying model}

In this study, three different mathematical models including the Page, Henderson and Pabis, and Logarithmic were applied to predict the reduction of moisture content during drying of plant materials as shown in Table 2. The reliability of each model was evaluated based on correlation coefficient $\left(\mathrm{R}^{2}\right)$, and root mean square error (RMSE) value at 3 different temperatures at 60,70 , and $80{ }^{\circ} \mathrm{C}$.

The results showed that Page model provided the best fit to the experimental drying data of Prai (Zingiber cassumunar Roxb.), turmeric (Curcuma longa Linn.), lemongrass (Cymbopogon citratus), kaffir lime (Citrus hystrix), and tamarind Leaves (Tamarindus indica Linn.) with $\mathrm{R}^{2}$ values of $0.9957,0.9979,0.9971,0.9989$, and 0.9954 , respectively and RMSE values of 0.01792 , $0.0124,0.0163,0.0105$, and 0.0232 respectively. The large value of $\mathrm{R}^{2}$ (closer to 1.0 ) means the model fit well with the drying dataset. The small RMSE value means the smallest error of the generated model. Here, the Page model provided the highest $\mathrm{R}^{2}$ and the lowest RMSE values suggesting that this model should be selected to represent the experimental data.
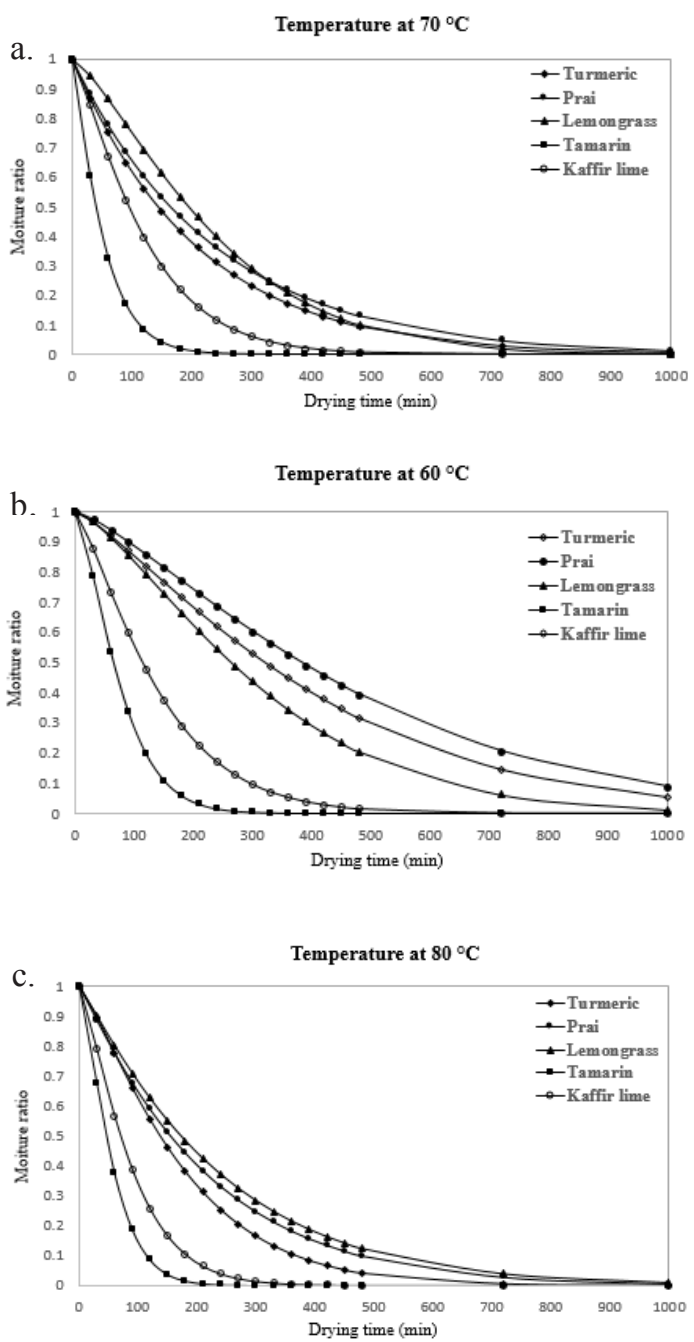

Figure 1. Drying behaviors of the herbs in herbal compress balls at (a) $60^{\circ} \mathrm{C}$, (b) $70^{\circ} \mathrm{C}$, and (c) $80^{\circ} \mathrm{C}$. 


\subsection{Effective moisture diffusivity $\left(D_{\text {eff }}\right)$}

During the drying process of herbs material, the drying rate could be determined by observation of the decreased rate of moisture content within a certain time period. The moisture transfer in the drying process is controlled by internal diffusion. The effective moisture diffusivity $\left(D_{\text {eff }}\right)$ could be explained by Fick's second law equation to describe the diffusion of water [22].

In this study, the values of effective moisture diffusivity $\left(D_{\text {eff }}\right)$ at different temperatures and particle sizes of herbs were determined. The calculated $D_{\text {eff }}$ values of each experiment were reported in Table 3. It could be observed that the higher drying temperature yielded the higher $D_{\text {eff }}$ values. For the particle size or the size reduction effect, the $\mathrm{D}_{\text {eff }}$ values was higher in cut sample (smaller particle size). For example, at $80^{\circ} \mathrm{C}$, Prai (Zingiber cassumunar Roxb.) has effective moisture diffusivity $\left(D_{\text {eff }}\right)$ value of $1.32 \times 10^{-3}$ and $1.93 \times 10^{-2} \mathrm{~m}^{2} / \mathrm{s}$ for large size (uncut sample) and small size (cut sample). This observation suggested that the size reduction increased $D_{\text {eff }}$ values because the small particle has the larger surface area than the big particle [23, 24].

\section{Conclusion}

The results showed that the drying temperature have an influence on drying behavior of herbs. The rate of reduction of moisture ratio was found to increase with increase the temperature suggesting that drying at higher temperature could reduce the herb preparation in compress ball. Here, Page model is the most fit to the experimental data compared to others model. In addition, the particle size of herb materials affected to the effective moisture diffusivity $\left(D_{\text {eff }}\right)$ values, that is, the reduction of particle size increase the diffusion of water. Therefore, the knowledge of this study could be further applied to the production and preparation process for commercial herbal compress for export sale.

\section{Acknowledgment}

The authors would like to thank National Science and Technology Development Agency (NSTDA with STEM program), Srinakarinwirot University (Research grant No. 540/2560) and TF Cosmetology Co. LTD. for the financial support of this research.

\section{References}

1. P. Yasarin, M. Sriariyanun, and T. Phusantisampan, KMUTNB Int J Appl Sci Technol, 9 (2016)

2. N. Chiranthanut, N. Hanprasertpong, and $\mathrm{S}$. Teekachunhatean, Hindawi Publishing Corporation BioMed Research International, vol. 2014, (2014)
3. W. A. S. Tunjunga, J. Cinatl jr. , M. Michaelisc, C. M. Smales, Procedia Chemistry, 14 (2014)

4. P. Kuru, Asian Pacific Journal of Tropical Biomedicine, 4 (2014)

5. Y. Zhang, X. Jiang, K. Peng, C. Chen, L. Fu, Z. Wang, J. Feng, Drug Des Devel Ther, 8 (2014)

6. M. Ranitha, Abdurahman H. Nour, Ziad A. Sulaiman, Azhari H. Nour, and Thana Raj S., International Journal of Chemical Engineering and Applications, 5 (2014)

7. W.Poomanee, W. Chaiyana, N.intasai, P. Leelapornpisid, Article in International Journal of Pharmacy and Pharmaceutical Sciences, 7 (2015)

8. Z. Erbay and F.Icier, Critical Reviews in Food Science and Nutrition, 50 (2009)

9. A.Tahmasebi, J. Yu, X. Li, C. Meesri, Fuel Process. Technol. ,92 (2011)

10. A.T. Garavanda, S. Rafieea, A. Keyhania, Journal of Engineering, Management, \& Applied Sciences \& Technologies, 2 (2011)

11. T.O. Olurin, A. O. Adelekan, W. A. Olosunde, Agric Eng Int: CIGR Journal, 14 (2012)

12. E. N. Wami and M. O. Ibrahim, International Journal of Scientific \& Engineering Research. 5 (2014)

13. M. Aghbashlo, MH. Kianmehr, S. Khani, M.Ghasemi, Int. Agrophysics, 11 (2017)

14. P. Gupta, J. Ahmet, U.S. Shivhare, G.S.V. Raghavon Drying technology, 20 (2007)

15. R. Kabganian, D.J. Carrier, S. Sokhansanj, Drying Technology, 20 (2007)

16. S. J. Temple, A. J. B. Boxtel, Journal of Agriculture and Engineering Research, 74 (1999)

17. Z. Erbay, F. Icier, Critcal Reviews in Food Science and Nutrition, 50 (2010)

18. N. Sinha,Y. H. Hui, E. Özgül Evranuz, M. Siddiq, J. Ahmed, Handbook of Vegetables and Vegetable Processing, (2010)

19. P. Simha, M. Mathew, M. Ganesapillai, Journal of Alexandria Engineering, 55 (2016)

20. B.D.A. Porciuncula, M.F. Zotarelli, B.A.M. Carciofi, J.B. Laurindo, Journal of Food Engineering, 119 (2013)

21. A.S. Mujumdar, and A.S. Menon, Drying of Solids: Principles, Classification, and Selection of Dryers. In: Handbook of Industrial Drying, 2nd ed. New York. Marcel Dekker Inc., (1995)

22. F.M. Botelho, P.C. Corrêa, A. L. D. Goneli, M. A. Martins, F.E.A. Magalhães and S. C. Campos, Revista Brasileira de Engenharia Agrícola e Ambiental, 15 (2011)

23. K.Y. Kone, Z.E. Gnimpieba, D. Soro, N.E. Assidjo, J.C. Laguerre, Asian Journal of Agriculture and Food Sciences, 5 (2017)

24. S. Chaichoowong, J.B. Bol, P. Bol, T. Gamse, M. Sriariyanun, Oriental Journal of Chemistry, 33, 66 (2017) 